\title{
Membaca Gejala "Mediatisasi”" Politik di Indonesia
}

\author{
Noveri Faikar Urfan \\ Mahasiswa Pascasarjana Ilmu Komunikasi \\ Universitas Gadjah Mada, Yogyakarta.
}

\begin{abstract}
Mediatization is considered as a process oriented of high modernity in which the media become an independent institution with logic of its own that other social institution accommodate to, especially politics. In the past, the media were the subordinate of politics, because the process of communication is centralized by political institution, in particular by political party, so the media were dominated by political logic. But now, after taking a large proliferation, media become omnipresent, so the logic of the media is widespread to any other social institutions. In some degree, politics have to accommodate the media logic. The logic of the media refers to the function of media as the "medium", and constructing symbolic resource.
\end{abstract}

Keywords: mediatization, mediatization as the process oriented, media logic, mediatization in Indonesia.

\begin{abstract}
Abstrak
Mediatisasi dipandang sebagai sebuah proses orientasi dari modernitas, saat media menjadi lembaga independent dengan logikanya sendiri. Lembaga sosial lainnya - terutama politik harus mengikuti logika tersebut. Di masa lalu, media merupakan subordinat dari politik, karena proses komunikasi dilakukan secara terpusat oleh institusi politik, secara khususnya partai politik. Karenanya, media mejadi didominasi oleh logika politik. Namun sekarang, setelah melakukan perubahan besar-besaran, media menjadi semakin meluas dan logika media kini tersebar hingga ke lembaga sosial lain. Pada titik yang sama, politik harus mengakomodasi logika media. Logika media sendiri merujuk pada fungsi media sebagai "medium", dan mengkonstruksi sumber daya simbolis.
\end{abstract}

Kata Kunci: mediatisasi, mediatisasi sebagai proses, logika media, mediatisasi di Indonesia

\section{Pendahuluan}

Pasca lengsernya Soeharto dan bergulirnya reformasi, dunia politik menjadi semacam perayaan. Salah satu parameternya dibuktikan dengan banyaknya partai politik yang ikut serta dalam pemilu. Jika dulu kita hanya mengenal tiga kandidat tetap partai peserta pemilu, pasca reformasi kita berhadapan dengan 24 partai di pemilu 2004, dan 38 partai pada 2009, jumlah yang tidak terbayangkan sebelumnya. Tidak seperti masa Orde Baru (Orba), ketika persoalan politik sangat sensitif untuk diperdebatkan, kini politik tidak lagi "tabu" untuk diributkan, bahkan terkesan buka-bukaan. 
Isu politik tampak sudah menjadi bagian dari keseharian masyarakat dewasa ini. Hal ini wajar, sebab sehari-hari dan kapanpun kita bisa mengikuti isu-isu politik di televisi, radio, media cetak, dan media online. Kita juga semakin akrab dengan debat-debat politik di media massa. Di masa Orba, debat politik relatif tabu, namun sekarang kita tidak kaget melihat politikus saling lempar argumen dan alasan, bahkan saling memaki.

Tidak bisa dipungkiri, media massa menjadi katalisator dalam perubahan keseharian politik di negeri ini. Dulu, politik menjadi semacam persoalan "sakral" yang harus ditutupi melalui sikap represif penguasa, media pun tidak bisa sembarangan menyentuh persoalan yang dianggap sensitif oleh rezim penguasa itu. Sekarang, setelah industri media massa berkembang pesat, persoalan politik tidak lagi tabu dibicarakan sehari-hari. Media massa mengabarkannya dengan cepat dan terus-menerus. Politik tidak lagi sakral, bahkan terkesan "banal", karena informasinya di media massa membludak di tengah keseharian masyarakat.

Dari fenomena ini, penulis melihat bahwa ada pergeseran kultural dalam keseharian persoalan politik dewasa ini, secara khusus dalam relasinya dengan media massa. Pada masa Orde Baru, media massa menempati posisi subordinat atas wilayah kekuasaan, sehingga persoalan politik tidak banyak riuh akibat proteksi rezim. Bagi media massa kala itu, mempunyai hubungan dekat dengan rezim adalah kunci penyelamat dari ancaman pembredelan. Menapaki masa reformasi, sejumlah konsolidasi dan pembaharuan dilakukan untuk membebaskan media dari cengkeraman rezim. Kini, peta kekuatan seolah berbalik 180 derajat, media massa semakin kuat, bahkan terasa lebih dominan dari politik itu sendiri.

Media massa dengan mudah mengabarkan isu-isu politik tiap hari, mengundang pengamat atau ahli, politukus ternama, pengacara tenar, dan mempertemukan mereka dalam satu forum. Ini artinya, media massa hari ini sudah memiliki bargaining position yang luar biasa terhadap politik. Di tengah posisi media yang kian kuat ini, kultur politik ditengarai juga ikut bergeser. Pergeseran itu agaknya terasa ketika dewasa ini, aktor-aktor politik semakin membutuhkan media atau mengadopsi gaya media sebagai bagian dari dirinya sebagai politikus.

Pada realitasnya, keadaan ini bisa digambarkan misalnya; partai-partai politik banyak merekrut selebriti yang tenar di media untuk mendongkrak popularitas dan citra partai, selain itu, kecakapan untuk memutar (spinning) informasi "bersilat lidah" menjadi kriteria penting bagi kader partai sebab kecakapan tersebut sangat dibutuhkan ketika berhadapan dengan media. Hal ini, menunjukkan bahwa "citra di media" menjadi sangat penting bagi institusi dan aktor politik. 
Gejala tersebut juga bisa diamati, misalnya dalam fenomena semakin maraknya aktor-aktor politik muncul di media, khususnya di televisi, dalam kapasitasnya tidak semata sebagai aktor politik, tapi juga "bintang media", seperti menjadi bintang iklan dan pemain sinetron. Ada beberapa tokoh politik yang bisa disebutkan, seperti mantan Ketua MK, Mahfud M.D yang menjadi bintang iklan obat masuk angin, Ketua DPR, Marzuki Alie, yang membintangi iklan pabrikan alat rumah tangga, dan Menteri BUMN, Dahlan Iskan yang bermain di salah satu sinetron religi dalam dua episode, sekaligus membintangi iklan obat masuk angin.

Di luar alasan subjektif para tokoh politik yang menerima tawaran menjadi "bintang media" tersebut, penulis melihat bahwa terdapat gejala semakin banyak aktor politik dewasa ini yang merasa sangat membutuhkan pembentukan citra di media massa. Jika secara normatif, seharusnya citra institusi atau aktor politik dicapai dengan upaya perumusan program dan kebijakan bagi publik, maka bagi institusi dan aktor politik dewasa ini, indikator ketenaran di media massa agaknya lebih dipikirkan ketimbang program dan kebijakan.

Keadaan ini melukiskan bahwa ada semacam dominasi dari cara berpikir media atas politik. Dalam derajat tertentu, politik mulai kehilangan substansinya sebagai persoalan terkait kebijakan publik, dan tergerogoti oleh perilaku-perilaku bersifat pencitraan. Hal ini menandakan bahwa dewasa ini institusi atau aktor politik semakin tergantung dan dibentuk oleh "logika" media massa.

Gejala inilah yang kini mulai banyak dibicarakan dalam kajian mediapolitik, khususnya komunikasi politik. Fenomena ini disebut "mediatisasi" (mediatization), konsep ini dipakai untuk menggambarkan terjadinya ekspansi logika media terhadap politik dan ketergantungan institusi atau aktor politik pada media (Stromback, 2008). Dalam proses yang hampir sama gejala ini disebutkan oleh Mayer (2002) dengan "mediacracy" untuk menggambarkan terjadinya praktik kolonisasi oleh permainan media pada dunia politik (media steering politics). Secara lebih luas, Hjarvard (2008) menyebutkan bahwa ekspansi logika media tidak hanya merambah pada politik, akan tetapi ikut merasuk secara kultural pada institusiinstitusi sosial yang lain, termasuk institusi keagamaan, pendidikan, bahkan keluarga.

\section{Mediatisasi Politik}

Konsep mediatisasi sendiri awalnya dipakai untuk menjelaskan dampak media terhadap komunikasi politik dan beberapa aspek dalam politik. Dalam riset terdahulu, konsep mediatisasi dipakai untuk melihat fenomena ketika dalam aspek tertentu, sistem politik telah disesuaikan dan terpengaruh secara kuat 
oleh tuntutan media massa dalam mengulas (coverage) persoalan politik (Hjarvard, 2008). Keadaan ini salah satunya diadaptasi dari kecenderungan materi dan cara-cara tertentu para politikus dalam menyampaikan pesanpesan politik kepada publik, agar pesanpesan itu terdengar manis di hadapan media.

Maka, keadaan ini mengandaikan bahwa media massa dalam cara kerjanya menjadi relatif tidak tergantung dari sumber informasi politik. Justru institusi politik (lembaga pemerintah, politikus, dan partai politik) sebagai sumber informasi politik menjadi kurang independen dari media, sehingga mereka menerapkan cara-cara tertentu untuk melindungi diri dari ulasan media yang berisiko menimbulkan citra buruk bagi eksitensi dirinya.

Konsep mediatisasi sendiri lebih dipandang sebagai suatu proses (processoriented). Stig Hjarvard (2008: 106) melihatnya sebagai proses kultural yang mengubah karakter dan fungsi institusiinstitusi sosial akibat respon atas ekspansi atau kehadiran media secara meluas (media omnipresence). Hjarvard lantas mengajukan dugaan atas perkembangan karakter institusi media massa secara periodik-historis dalam relasinya dengan institusi politik. Perkembangan ini disesuaikan dengan konteks Eropa, Hjarvard menjelaskannya dalam tiga periode. Periode pertama 1920 ke belakang, kedua 1920-1980, dan ketiga 1980 ke depan.

Pada periode pertama (-1920), media massa dianggap sebagai instrumen dari institusi sosial, media massa cenderung dimanfaatkan oleh institusi politik sebagai alat agitasi dan propaganda, sehingga posisinya menjadi subordinat dari institusi politik. Periode kedua (1920-1980), media massa dijalankan atas logika kepentingan publik, atau bagian dari sarana publik, sehingga kehadirannya ditujukan untuk melayani publik. Sementara pada periode ketiga (1980-kini), media massa menjadi relatif independen dari institusi sosial dan logika dominannya adalah kerja professional, bisnis, dan panduan kapasitas teknis.

Dalam memaknai periode yang disebutkan Hjarvard, tentu saja dibutuhkan pengandaian yang lebih jelas tentang proses terbentuknya gejala mediatisasi politik itu sendiri. Pada dasarnya, terdapat perbedaan antara logika politik dan logika media, akan tetapi dalam proses mediatisasi sebagai hasil, logika media massa kemudian menekan politik sehingga mau tidak mau politik kemudian dalam derajat tertentu menginternalisasi logika media ke dalam dirinya.

Konsep logika politik itu sendiri, setidaknya selalu berhubungan dengan pengambilan keputusan kolektif dan otoritas pembuatan kebijakan maupun implementasi atas keputusan politik. 
Termasuk di dalamnya terdapat proses distribusi kekuasaan melalui pemilihan umum atau sarana yang lain; proses pembuatan keputusan; dan petanyaan tetang kekuasaan, "siapa mendapatkan apa, kapan, dan dengan cara bagaimana” (Strombach, 2008).

Sementara logika media (media logic) mengacu pada proses dan asumsi dalam konstruksi pesan-pesan melalui medium tertentu, khususnya terobosan teknologi komunikasi (Altheide, 2004). Ini menunjukkan bahwa logika media mengacu pada fungsinya sebagai "medium" yang juga agen konstruksi pesan, dan dalam derajat tertentu fungsinya sebagai medium bisa dipersoalkan sebagai "pesan" itu sendiri (McLuhan, 1995).

Antara logika media dan logika politik memang terdapat perbedaan, akan tetapi pada realitasnya kedua logika ini saling besinggungan. Dalam membicarakan proses mediatisasi politik, kita juga harus melihat pola hubungan antara institusi politik dan media yang terus bergerak. Strombacah (2008) membantu melihat ini dengan berusaha mempertanyakan, mana yang lebih dominan antara logika politik atau logika media? Apakah politik menyetir media atau media yang menyetir politik?

Tentu saja, pertanyaan-pertanyaan ituharus diletakkan dalam derajat tertentu sebab mediatisasi sendiri bukanlah efek total ketika media benar-benar mengambil kuasa penuh atas politik, akan tetapi media dengan logikanya semakin banyak diadopsi dan terinternalisasi menjadi bagian dari politik.

Dalam dinamika tersebut, upaya memberikan pemahaman secara konseptual atas proses mediatisasi menjadi penting. Blumler dan Kavanagh (1999) misalnya, mengajukan gambaran tentang tiga era komunikasi politik. Sebagai contoh ia mengungkapkan bahwa ada masa ketika debat-debat politik terasa lebih substantif dan kurang terpengaruh oleh logika media, dalam era komunikasi politik pertama, masa ini adalah "era keemasan partai politik”, terjadi selama dua dekade setelah Perang Dunia kedua.

Pada masa ini, komunikasi politik berpusat pada partai politik. Media massa kala itu berada dalam posisi subordinat, di pinggir-pinggir titik pusat lingkaran yang dikuasai oleh partai politik. Pesan-pesan politik pada massa itu dinilai lebih substantif sebab aktor-aktor politik cenderung berbicara tentang isu-isu yang penting bagi mereka, terutama tentang perubahan yang mereka inginkan dalam pemerintahan yang membedakan dia dengan lawan politiknya (Blumler \& Kavanagh, 1999: 212).

Posisi partai dan tokoh politik pada masa ini cenderung independen dari media. Institusi dan aktor politik menjadi pusat komunikasi, sedangkan media menempati posisi kurang independen, yakni sebagai sebatas medium untuk 
menyampaikan pesan-pesan politik yang bersumber dari institusi dan aktor politik, atau menjadi kepanjangan tangan dari persaingan politik atas partai dan tokoh politik tertentu (media participant).

Setelah era komunikasi politik pertama, Blumler dan Kavanagh menyebutkan terjadinya era komunikasi politik kedua dan ketiga. Era komunikasi politik kedua, ditandai dengan masuknya siaran televisi di sekitar tahun 1960, disusul oleh menguatnya komitmen norma-norma media nonpartisan, seperti netralitas, cover both side, dan berbagai tuntutan jargon profesional serta independensi media terhadap politik. Dalam era komunikasi politik kedua ini, posisi media menguat. Media mulai memisahkan diri dengan kepentingan politik partisan, dan memilih jalur independensi serta profesionalitas. Keadaan ini, membuat institusi politik dan aktor politik mulai kehilangan kendali atas media. Maka proses komunikasi politik tidak lagi berpusat kepada partai atau tokoh politik seperti pada era komunikasi politik pertama, melainkan dalam derajat tertentu komunikasi politik harus menyesuaikan diri dengan posisi media massa yang mulai independen.

Sementara dalam era komunikasi politik ketiga, ditandai dengan semakin berkembangbiaknya sarana komunikasi, keberlimpahan media, jangkauan dan kecepatan informasi yang semakin tinggi. Keadaan ini kemudian mengubah cara masyarakat menerima pesan-pesan politik. Pada era komunikasi politik pertama, pesan-pesan politik relatif bersih dari campur tangan konstruksi media. Kini, ketika media massa semakin melimpah dan jangkauannya kian luas, pesan-pesan politik mulai terjebak dalam arena konstruksi media, sehingga seringkali kehilangan substansi.

Dalam derajat tertentu, institusi dan tokoh politik mulai merespon gejala ini dengan cara-cara tertentu untuk meminimalisir risiko citra negatif bagi dirinya yang bisa ditimbulkan oleh media. Blumler dan Kavanagh, lalu mengibaratkan perkembangbiakan industri media, seperti binatang hidra berkepala banyak (a hydra-headed beast) yang masing-masing mempunyai mulut dan meminta untuk diberi makan. Pengibaratan ini sebenarnya ditujukan untuk melihat gejala bahwa institusi dan aktor politik semakin dikepung oleh banyaknya media massa, di mana masingmasing media selalu ingin mengorek informasi dalam persoalan politik.

Keadaan ini akhirnya menuntut institusi dan aktor politik untuk mulai memikirkan cara-cara tertentu agar bisa berhubungan secara efektif dengan media yang semakin banyak. Dalam menyikapi hal ini, institusi dan aktor politik secara umum mulai menganggap penting adanya terobosan dalam membangun program kehumasan, khususnya media relations. Hubungan yang baik dengan media dianggap akan memberi dampak positif bagi institusi dan aktor politik, terutama 
untuk mendorong citra dan meningkatkan elektabilitas.

Dalam gejala tertentu, banyak aktor politik yang bahkan menganggap bahwa menjadi "kekasih media" (media darling) bisa mendorong kesuksesannya sebagai aktor politik. Artinya, dalam era komunikasi politik ketiga ini, institusi dan aktor politik semakin terpengaruh oleh determinasi media terhadap politik. Sehingga dalam derajat tertentu, institusi dan aktor politik harus berusaha menyesuaikan gaya mereka terhadap keinginan media.

Selain Blumler dan Kavanagh, Jesper Strombach (2008) juga cukup membantu dalam menganalisis proses mediatisasi politik dengan mengajukan empat fase dalam menganalisis proses mediatisasi. Pada awalnya, menurut Strombach, ada pengakuan bahwa media massa menjadi sumber informasi yang penting bagi politik, isu-isu politik mulai ramai di media massa. Sampai pada suatu fase, media massa menjadi lebih independen terhadap politik, dan proses mediatisasi politik menguat ketika aktor dan institusi politik sudah mengikuti logika media dan menjadikannya sebagai bagian dari dirinya.

Media massa pada awalnya menjadi sarana bagi politik, katakanlah sebagai medium bagi institusi politik untuk menyebarluaskan kepentingannya. Media kemudian menjadi penting bagi politik untuk menjadi media bagi kepentingan politik tertentu agar tersebar secara massif. Ini adalah fase awal ketika masyarakat mulai meyadari betapa pentingnya media sebagai saluran informasi dan memiliki dampak yang kuat, keadaan ini yang disebut Strombach (2008) sebagai fase mediatisasi politik pertama (the first phase of mediatization).

Masa ini sering disebutkan ketika Perang Dunia pertama dan kedua, ketika media massa dimanfaatkan sebagai alat propaganda. Konteks historis ini bisa juga dipahami bahwa media massa (khususnya media cetak) berperan besar dalam membentuk kesadaran nasional pasca perang dunia, atau "nasionalisme cetak" dalam bahasan Benedict Anderson tentang Imagined Communities (1991), sejak itu media massa dianggap sebagai medium yang ampuh dalam memobilisasi massa.

Dalam fase mediatisasi kedua (second phase of mediatization), media mulai independen dari pemerintahan. Media terus berusaha melepaskan diri dari cengkeraman rezim dan berusaha memetakan arahnya sendiri, melalui aturan-aturan profesional. Akan tetapi media tidak sepenuhnya independen dari politik, sebab masih beroperasi dalam batas-batas aturan institusi politik. Fase kedua ini menggambarkan adanya sebuah transisi dari fase yang pertama.

Media mendapat kesempatan yang kian luas dalam bersikap daripada fase 
yang pertama, media kian otonom dalam membangun opini publik sesuai norma dan nilai mereka sendiri. Akan tetapi, dalam fase transisi ini logika politik masih relatif kuat, dan media dalam derajat tertentu menjadi semi-independen. Dalam pengertian media massa masih bergelut soal "negosiasi kelayakan berita" (negotiation of news worthynes) bersama aktor dan institusi politik. Politik tidak bisa lagi mengendalikan penuh wacana dalam konten media, akan tetapi media juga belum sepenuhnya mampu mengendalikan wacana politik.

Pada fase mediatisasi ketiga (third phase of mediatization), media menjadi lebih independen lagi dari fase yang kedua. Media terus bergerak ke arah jargon profesionalitas, dan mengukuhkan dirinya sebagai institusi yang mandiri secara ekonomi karena pasarnya kian menguat. Institusi dan aktor politik pun menganggap media massa sebagai faktor eksternal yang layak diberi tempat. Institusi dan aktor politik mulai mengakrabi media untuk mendorong kesuksesan karirnya. Logika media terus terinternalisasi dalam politik, sehingga institusi dan aktor politik kian menyadari pentingnya mengadopsi cara kerja media pada tingkah laku berpolitik. Keadaan ini diandaikan dengan mulai gencarnya institusi dan aktor politik melibatkan media dalam kampanye, atau memanfaatkan press release untuk mendorong citra.
Sementara pada fase keempat (fourth phase of mediatization), logika media semakin terinternalisasi dalam logika politik. Institusi dan aktor politik berfikir bahwa mereka tidak hanya bergandeng dengan media ketika kepentingan kampanye, tapi juga dalam merumuskan kebijakan. Kaderisasi politik juga memperhatikan kecakapan berinteraksi dengan media, memutarmutar (spinning) argumen dalam debat di media, serta selebritis mendapat tempat yang signifikan dalam politik atas pertimbangan akan mendongkrak citra politik (Blumler \& Kavanagh, 1999).

\section{Proses Mediatisasi Politik di Indonesia?}

Pada bahasan sebelumnya, sudah diamati bagaimana proses mediatisasi terjadi. Blumler and Kavanagh (1999) mengajukan konsep tiga era dalam komunikasi politik, sementara Hjarvard (2008), mengajukan periodisasi dalam konteks Eropa, dan Strombach (2008) menunjukkan empat fase dalam mediatisasi politik. Melihat pembahasan tersebut, kemudian bisa diajukan pertanyaan, lantas bagaimana proses mediatisasi di Indonesia?

Penulis merasa, empat fase mediatisasi yang ditawarkan oleh Strombach (2008) agaknya cukup relevan untuk diterapkan dalam melihat proses mediatisasi di Indonesia. Meskipun proses itu harus didudukkan dalam periodisasi 
historis agar pergeseran atau dinamika dalam proses itu menjadi kelihatan. Tentu saja, periodisasi historis ini tidaklah mutlak, apa yang diajukan Hjarvard adalah sebuah konteks khusus, yang sedikit banyak akan berbeda dengan konteks Indonesia.

Pada masa pemerintahan Orde Lama dan Orde Baru, posisi media yang subordinat di pinggir struktur politik, bisa dianggap sebagai fase pertama atau fase awal proses mediatisasi di Indonesia. Media dimanfaatkan oleh institusi politik untuk menjalankan kepentingan politik tertentu. Dalam fase ini, logika politik terasa mendominasi logika media. Politik begitu dominan terhadap media massa, sehingga secara umum media dianggap sebagai kepanjangan dari kepentingan politik.

Keadaan ini, bisa dikaitkan dengan misalnya, maraknya media partisan pada era demokrasi liberal tahun 1950-an. Masa demokrasi liberal tahun 1950-1959 bisa dianggap sebagai era keemasan partai politik, sebab partai politik memegang kendali dalam proses komunikasi politik pada masa itu. Pada Pemilu pertama di Indonesia tahun 1955, jumlah partai politik peserta pemilu membludak dengan jumlah lebih dari 30 partai dengan memegang bermacam ideologi. seperti sosialis, komunis, nasionalis, Islam, dan sebagainya.

Tuntutan kompetisi politik yang luar biasa ini memunculkan fenomena media partisan sebagai kepanjangan tangan dari kepentingan partai politik. Di antara banyak media partisan pada masa itu, bisa disebut misalnya koran-koran partisan dengan oplah terbanyak: Harian Rakyat milik PKI (55.000 eksemplar/hari), Pedoman milik PSI (48.0oo eksemplar/hari), Soeloeh Indonesia milik PNI (40.000 eksemplar/hari), dan Abadi milik Masyumi (38.ooo eksemplar /hari) (Said, dalam Latif, 2005: 380). Fenomena media partisan ini melukiskan gejala bahwa media menempati posisi subordinat di bawah struktur politik, sehingga media cenderung kurang independen terhadap institusi politik.

Masa setelah demokrasi liberal tahun 1950-1959, yakni masa Demokrasi Terpimpin dan Orde Baru, juga masih bisa dikategorikan dalam fase mediatisasi pertama, sebab media massa masih menduduki posisi subordinat dari wilayah kekuasaan. Meskipun memang, pada masa Orde Baru embrio munculnya media (pers) yang independen mulai bermunculan, tetapi masih dihantui oleh bayang-bayang penguasa dengan ancaman pembredelan.

Pada masa pergulatan reformasi, sejumlah upaya dilakukan untuk membebaskan media massa dari belenggu rezim, media pun mulai terbuka untuk membicarakan isu-isu politik dan mengkritik pemerintah. Pada masa ini logika media kian menguat, kedudukan media menjadi makin otonom. Akan 
tetapi, pada masa ini, posisi media masih relatif tergantung pada batas-batas institusi politik. Penulis menganggap masa ini sebagai fase mediatisasi kedua. Sebagaimana kita ingat, masa reformasi adalah masa transisi dari rezim otoriter menuju demokrasi. Berbagai konsolidasi dan upaya pembaruan dilakukan untuk mengatasi keadaan negara yang krisis.

Menariknya, pada masa ini isu-isu politik yang substansial menjadi ramai dikabarkan, kalau kita ingat seperti isu tentang gagasan federalisme dan ekonomi kerakyatan (Panggabean, 1998). Dalam fase transisi ini antara logika politik dan logika media relatif lebih seimbang, atau boleh dikata dalam derajat tertentu media massa menjadi semi-independen. Dalam pengertian media massa masih bergelut soal "negosiasi kelayakan berita" (negotiation of news worthynes) bersama aktor dan institusi politik. Politik tidak bisa lagi mengendalikan penuh wacana dalam konten media, akan tetapi media juga belum sepenuhnya mampu mengendalikan wacana politik.

Setelah masa transisi reformasi sampai dewasa ini bisa dianggap sebagai fase mediatisasi ketiga dan keempat. Fase ketiga menampakkan dominasi logika media atas logika politik semakin menguat. Institusi dan aktor politik makin sering bekerjasama dengan media untuk meraih kesuksesan karir politik, seperti memanfaatkan media massa untuk kampanye. Politik yang dibicarakan oleh para politikus, makin mengarah pada motivasi penguatan citra di media massa, bukan menguatkan bahasan atas program politik.

Dalam derajat tertentu, logika politik juga ditengarai ikut bergeser dan menginternalisasi logika media. Misalnya, praktik kaderisasi selebritis oleh partai politik yang kian marak. Pada pemilu 2004 misalnya nama-nama aktris mulai banyak bermunculan di DPR seperti Angelina Sondakh (Demokrat), Rieke Dyah Pitaloka (PDIP), pada 2009 jumlah selebritis yang berkarir di DPR meningkat jumlahnya menjadi 18 orang. Keadaan ini mengandaikan bahwa popularitas di media kian menjadi pertimbangan bagi kader partai politik. Dalam derajat tertentu, sosialisasi program-program politik menjadi kurang esensial. Misalnya dalam kampanye, substansi program politik semakin berkurang dan tergantikan oleh kampanye yang sifatnya populer dan hanya mengedepankan citra seperti iklan politik di televisi (Plasser, 2001).

Pada fase mediatisasi keempat, logika media kian ekspansif, hal ini mebuat institusi politik sangat mementingkan kapasitas kadernya dalam berinteraksi dengan media. Misalnya kecakapan memutar (spinning) informasi, debat di media, serta selebritas mendapat tempat makin signifikan untuk menunjang citra partai. Persoalan substantif tentang kebijakan dan program politik mulai kehilangan esensinya, digantikan oleh ramainya perdebatan 
banal, hingga terlihat batas antara "yang politik" dengan "yang media" menjadi kian kabur.

Fase mediatisasi keempat ini, bisa dipandang sebagai hasil agregat dari proses-proses sebelumnya. Pada fase ini, dalam derajat tertentu media begitu mendominasi politik. Misalnya, kini sangat marak televisi menyajikan acara debat-debat politik, salah satu yang fenomenal, misalnya Indonesian Lawyers $C l u b$ di TVOne. Dengan mudahnya televisi mengundang aktor politik senior, pengacara tenar, budayawan, dan pengamat, lalu mempertemukan mereka dalam satu forum debat politik. Alih-alih acara ini kemudian menghadirkan wacana politik yang sehat dan mencerdaskan publik, justru seringkali perdebatan politik di dalamnya menyajikan wacana politik yang penuh caci maki, tidak substantif dan rusuh.

Kecenderungan

ini, mengindikasikan adanya dominasi media massa dalam menggiring wacana politik (media steering politics). Logika media kemudian membawa wacana politik terjebak dalam banalitas. Selain itu, media massa makin dianggap sangat penting dalam politik, makanya tidak heran kemudian para konglomerat media massa beramai-ramai masuk dunia politik, seperti Surya Paloh, Abu Rizal Bakrie dan Hary Tanoesodibyo. Sebab dengan menguasai media sambil mempertahankan logikanya, bisa berarti jaminan terhadap citra, elektabilitas, dan kesuksesan karir politik.

Fenomena konglomerat media yang kian santer terjun ke pentas politik, dalam derajat tertentu mengindikasikan dominasi aktor politik dalam menyetir media, artinya media dimanfaatkan dalam agenda kepentingan politik tertentu. Jika begini, maka kita melihat ada kecenderungan bahwa logika politiklah yang mendominasi media. Akan tetapi, ketika menyebutkan konsep mediatisasi, keadaan agak berseberangan, sebab dalam proses mediatisasi sebagai hasil, logika media lah yang mendominasi logika politik.

Maka, di balik fenomena kepemilikan media saat aktor-aktor pemiliknya kini ramai terjun ke politik, penulis mengajukan argumen bahwa di satu sisi memang terdapat gejala dominasi kepentingan politik atas media. Namun di sisi lain, institusi dan aktor politik juga semakin terperangkap pada semacam "keimanan" bahwa mengikuti logika media adalah bagian dari kunci kesuksesan dalam pentas politik. Sebab, meskipun media itu dikuasai oleh aktor politik tertentu, aktor atau institusi politik itu tetap akan terperangkap dalam logika media dalam dosis yang relatif tinggi, terutama dalam soal pencitraan. Keadaan ini menggambarkan fenomena dominasi logika media terhadap logika politik. Politik menjadi terkesan banal dan kehilangan substansi, akibat adanya kolonisasi logika media. 
Buktinya, dalam praktik keseharian yang direpresentasikan oleh media massa, politik dewasa ini semakin kehilangan isu-isu yang substantif. Alihalih kita mengharapkan perdebatan ideologis, seperti masa perjuangan kemerdekaan atau masa transisi reforamasi, praktik politik hari ini didominasi oleh logika media. Pada akhirnya tema politik tidak mengikuti proses deliberasi dan komitmen mufakat, justru cenderung menghamburkan dramatisasi dan debat-debat minus substansi.

Maka, publik agaknya kian melihat politik sebagai isu yang banal, kecenderungan ini kemudian berimbas pada semakin tidak pedulinya masyarakat pada politik, dan dalam tingkatan partisipasi (pemilu) antusias publik pun menurun (Norris, 2000). Hal ini wajar, sebab publik seolah mengalami kejenuhan terhadap politik. Sebab, politik di media dewasa ini adalah politik yang telah mereduksi dirinya. Jika politik seharusnya bersifat ideologis dan berorientasikan program, kini politik yang kita saksikan di media semakin kehilangan substansi, malah makin mirip semacam sandiwara.

\section{Daftar Pustaka}

Altheide, David L. 2004. "Media Logic and Political Communication”. Political Communication. Vol. 21. No. 3, hal. 293-296.

Anderson, Benedict. 1991. Imagined Communities. London: Verso.

Blumler, Jay G. \& Kavanagh, Dennis. 1999. "The Third Age of Political Communication: Influences and Features". Political Communication. Vol. 16, hal. 209-230.

Hjarvard, Stig. 2008. "The Mediatization of Society". Nordicom Review. Vol. 29. No. 2, hal. 105-134.

Latif, Yudi. 2005. Inteligensia Muslim dan Kuasa: Genealogi Intelegensia Muslim Indonesia Abad Ke-20. Jakarta: Mizan.

Liverow, Leah A. 2009. "New Media, Mediation, and Communication Study.

Information, Communication, \& Society. Vol. 12. No. 3, hal. 303-325.

Norris, Pippa. 2000. A Virtuous Circle: Political Communication in Postindustrial Societies.

Cambridge: Cambridge

University Press.

Meyer, Thomas. 2002. Media Democracy: How the Media Colonize Politics. Cambridge: Polity Press. 
McLuhan, Marshall. 1995. Understanding

Media: The Extension of Man. Massachusetts: MIT Press.

Panggabean, Samsu Rizal. 1998.

"Federalisasi dan Demokratisasi Indonesia”. Jurnal Sosial Politik.

Vol. 1. No. 3. Fisipol UGM.

Plasser, Fritz. 2001. "Diminishing

Relevance for Campaign

Professional". The Harvard

International Journal of

Press/Politics. Vol. 6. London:

Sage Publications.
Sen, Krishna \& Hill, David T. 2001. Media, Budaya dan Politik di Indonesia. Jakarta: Institut Studi Arus Informasi (ISAI).

Strombach, Jesper. 2008. "Four Phases of Mediatization: An Analysis of the Mediatization of Politics". Press/Politics. Vol. 13. No. 3. London: Sage Publications. 
Jurnal komunikasi, Volume 6, Nomor 1, Oktober 2011 